\title{
Review of Ricardian Equivalence in Theory and Practice: Empirical Data from Nigeria
}

\author{
Auwal Isah ${ }^{1,}{ }^{\dagger}$, Joseph E. Tonuchi $2,3,{ }^{\dagger}$ and Ridwan Dairo ${ }^{2, *, \dagger}$ \\ ${ }^{1}$ Monetary Policy Department, Central Bank of Nigeria, Abuja and ${ }^{2}$ Babcock University, Ilishan Remo, Ogun, \\ Nigeria and ${ }^{3}$ Statistics Department, Central Bank of Nigeria, Abuja \\ * corresponding author:abugerrard89@gmail.com \\ ${ }^{\dagger}$ Auhtors Contributed equally.
}

\begin{abstract}
Background: This study investigates the Ricardian Equivalence (RET) in theory and practice particularly as it relates to Nigeria's economy. Methodology: The study employed Autoregressive Distributed Lagged (ARDL) model to establish both the long-run and short-run relationship between deficit financing and consumption. Findings: The study found no strong evidence to reject the Ricardian Equivalence using data from Nigeria's economy contrary to most literature reviewing RET in Nigeria. Specifically, the study found that deficit financing variables like debt, tax revenue, and government expenditure have a significant impact on consumption when the strict assumption of RET is not introduced in the model but became insignificant when the ratio of tax revenue to changes in debt is introduced in the model. The study concludes that Ricardian Equivalence is valid in the case of Nigeria when the strict assumption of RET is maintained but insignificant when the major assumption of RET is relaxed or when deficit finance variables enter the model indirectly. The study recommends that while government embraces deficit financing to stimulate the economy, it should be done with utmost care not induce stagflation thereby eroding the small gain from the stimulation.
\end{abstract}

Key words: ARDL, Consumption, Debt, ECM, Government, Inflation, Ricardian Equivalence Theory (RET), and Tax Disclaimer: The views expressed in this article are the author's own and do not reflect the view of any institution (s) the authors are affiliated to.

\section{Introduction}

The recent outbreak of Covid-19 pandemic across the globe which induced another phase of global economic recession has prompted several governments to adopt a series of economic recovery plans (Joseph; 2020). Top among this approach is the adoption of deficit financing (borrowing to augment income). Keynes believed that during the period of economic recession, the government can adopt deficit financing by either lowering tax rates or increasing their expenditure through debt and 'spending the economy out of recession' (Siddiki; 2010; Emana; 2021). In order words, Keynes believed that a rise in government debt due to tax reduction increases consumers' disposable income, and as such stimulates aggregate demand which is needed to lift the economy out of recession (Ogbuagu and Omojolaibi; 2020). In Keynesian postulation and proposition, consumers treat government debt as net wealth, hence, a replacement of debt for taxes may influence private consumption and aggregate demand positively. According to the Keynesian postulate, government finances or fiscal policy has the capacity of changing private consumption (aggregate demand) and savings in a country.

This belief has been largely criticized in the literature particularly because of its tendencies to create stagflation, erode the value of money, create concern for fiscal sustainability which invariably reverse the gains made in the short term. One of the main critics of Keynes's theory is 
the Ricardian Equivalence Theory (RET), which says that financing government spending out of current taxes or future taxes (and current deficits) will have equivalent effects on the overall economy, this also implies that Keynesian fiscal policy will generally be ineffective at boosting economic output and growth (Barro; 1989), meaning stimulating an economy by increasing debt-financed government spending as proposed by Keynes, will not be effective because investors and consumers understand that the debt will eventually have to be paid for in the form of future taxes. Specifically, RET believes that given an expenditure path, the substitution of debt for taxes does not affect private sector wealth and consumption. The underlying reasoning is that, under certain assumptions (perfect capital markets with no borrowing constraints, non-distortionary tax structure, certainty about future taxation and expenditures, and identical planning horizons for the private and public sectors), the issuance of new debt is associated with an anticipation of future taxation in the perceptions of rational agents (Ogbuagu and Omojolaibi; 2020; Saraswati and Wahyudi; 2018; Ezeabasili and Egbunike; 2014; Siddiki; 2010).

It states that, in a setting of an open economy, there is no correlation between the budget deficit and current account deficits (the popular twin deficit) and hence the former would not cause the latter. In other words, a change in governmental tax structure or a rise in public debt will not have any impact on the real interest rate, investments, or consumption (Umer and Ranjan; 2019). The consumer who is a rational being anticipates an increase in future taxes does not consider the current tax cut and its corresponding increase in his disposable income as being permanent. Thus, rather than increase his/her spending relative to the rise in disposable income save the money to pay for future tax raises. The assumption here is that consumption patterns of consumers will be based on the life cycle model formulated by Modigliani and Ando in 1957 (Modigliani and Ando; 1957) which suggests that current consumption depends on the expected lifetime income, rather than on the current income as proposed by the Keynesian absolute income hypothesis. Furthermore, the permanent income hypothesis developed by Milton Friedman in 1957 states that private consumption will increase only with a permanent increase in income. This means that a temporary rise in income fuelled by tax cuts or deficit-financed public spending will increase private savings rather than spending (Ayunasta et al.; 2020; Adji and Alm; 2016).

There are several cases of countries increasing the twin deficit (deficit finance and current account deficit) through rising debt, yet the aggregate demand is low and output rather than growing is deteriorating (Emana; 2021). This prompts one to ask, is fiscal policy effective particularly in developing countries, or is Ricardo all along right about no relationship between budget deficit and aggregate demand? Recent empirical studies reported a robust and significant impact of fiscal policy on the real economy (e.g., for the United States: (Romer and Romer; 2010; Favero and Giavazzi; 2012); for Germany (Hayo and Uhl; 2014); for the United Kingdom:(Cloyne; 2013); for Nigeria: (Abdulkarim and Saidatulakmal; 2021)). These empirical papers have cast doubt on Ricardian postulation.

Although studies showing the effectiveness of fiscal policy may cast doubt on RET validity, ultimately, they provide only indirect evidence of RET's usefulness for explaining empirical data. The general approach used has been to include government variables in a regression of private consumption on income and wealth in order to test whether the alternative methods of financing a given path of government expenditures have the same effects on private consumption, on the basis of sign and significance of the coefficients obtained. In employing this approach, the assumptions of the equivalence proposition are not explicitly tested and anticipated fiscal variables and expectations behaviour is not explicitly incorporated into the estimating model.

A serious criticism that may be pointed towards previous formulations is that the consumption function is not well specified. In particular, research on the validity of the equivalence proposition so far seems to disregard the fact that it is the changes in the ratio of taxes to government deficit which, in practice, should result in negligible effects on private consumption is what Ricardian theory emphasized. Therefore, the main interest in testing for the equivalence proposition lies in the combined effect of reducing taxes and increasing fiscal deficit (by using the corresponding partial derivatives), given the path of government expenditure. Such a combined effect may be best captured by the ratio of taxes to debt rather than the deficit variable in a stand-alone form. Thus, this study aims to fill this gap by reevaluating the Ricardian Equivalence Hypothesis in theory and practice using empirical data from Nigeria. The rest of the paper is structured into a review of literature (theoretical and empirical literature). Section three focused on the study methodology in terms of model specification, s technique of analysis, and sources of data. Section four presents and discusses the data while section five provides a tentative conclusion for the study.

\section{Review of Literature}

\subsection{Theoretical Foundation of Ricardian Equivalence}

RET argued that given an expenditure path, the substitution of debt for taxes does not affect private sector wealth and consumption. The theory is built on some assumption that is necessary for the hypothesis to hold (Bernd and Florian; 2017). Both Private and Public Expenditure Follow the same planning Horizon: The theory assumes that individuals and government must have the same time horizon, which is usually assumed to be infinite. If this assumption fails to hold, such that private consumer has a shorter time horizon than the government, the issue of new debt to be repaid in the future, after the probable death of that individual will imply an increase in the net wealth of the private consumer since the consumer will not have to contribute for the repayment of the principal when he/she is dead. However, Barro (1974) assumes the existence of an operational bequest motive. This implies that a private household is interlinked in a generational chain and assumed to live forever. Each individual cycle cares about the well-being of his (or her) descendants. In this case, the individual will not react to a tax cut by increasing its consumption immediately, instead will save the increased disposable income and possibly use it to invest, in doing so, the return would be used to cater for the future tax increase since the current tax cut is temporary. If people decide to invest in the bonds market with the extra part of the disposable income, that will be passed to the future generation that will eventually pay the burden of the debt. Similarly, households and families with constant consumption pattern regardless of the increase in their income, such tax cut would only result to an increase in disposable income without corresponding increase in aggregate demand which defeat the Keynes objective of tax cut (Adji et al.; 2009).

Capital Market is perfect and both household and government borrow at same interest rate: The capital market is never perfect and private, and government does not have access to credit at same rate. For instance, Carlos (2001) noted that 
"consumers are liquidity constrained if they face quantity constraints on the amount of borrowing (credit rationing) or if the loan rates available to them are higher than the rate at which they could lend (differential interest rates)". For instance, let assume a household that expects a future income higher than its current income. Their members would like to increase their current consumption. However, they face liquidity constraints that prevent them from obtaining the necessary funds in the capital market at the same interest rate as the government.

No Lump-sum Tax: Ricardian equivalence assumes lumpsum taxes. However, in reality, taxes are not lump-sum, they are a fraction of income. The tax liability is large if future income is high, and low if future income is low. This reduces the uncertainty about the household's lifetime resources, which may lead to an increase in current consumption (Romer and Romer; 2010). Also, one can argue that an assumed increase in future taxes might induce the consumer to attempt of transferring income from the future to the present, reducing saving and capital accumulation with tax reduction. Again, as argued by Castro and Fernandez (2013), if we assume that the more liquidity-constrained households are the ones that have low income, then their share of the tax liability associated with the bond issue is small. Therefore, their collateral and their probability of obtaining funds in the market is relatively unaffected by the increase in taxes. Thus, a tax cut will have a positive effect on their consumption (Bernd and Florian; 2017)).

Excess sensitivity of consumption to current income: The Ricardian equivalence will fail if individuals do not optimize consumption fully over long horizons (Castro and Fernandez; 2013). When the consumers put great weight on current or present disposable income, an increase in current consumption is expected as a response rise in disposable income. The consumption function has been found to be more sensitive to fluctuations in current income than it is forecasted by the permanent-income consumption model, because of the presence of non-optimising rule-of-thumb consumers (Nanshuwan and Omotunde; 2017).

The perfect foresight assumption: This assumption is difficult to sustain and achieve because individuals are not always rational and secondly do not tend to have close to perfect future foresight. This assumption is difficult given the uncertainty associated with the world and humanity. When this assumption is relaxed and an uncertain environment with inflation risk and default (or solvency) risk emerges, non-equivalence results do arise (Bernd and Florian; 2017).

In summary, looking at the theoretical assumptions of the Ricardian hypothesis, it is easy to discard RET given that most of the assumptions are difficult to hold in real sense. However, as argued by Carlos (2001), the theoretical restrictiveness of RET does not constitute to a practical refutation of model validity. This was consistent with the argument by Saraswati and Wahyudi (2018) that it is easy to theoretically raise facts that can invalidate strict RET yet RET provides useful information to assess the first-order effects of fiscal policy on the real sector. For this reason, it is important to examine the model with empirical facts.

\subsection{Empirical Literature}

Several studies have investigated the validity of RET following different routes. Three distinct strands of approach exist in empirical literature. The first and most popular approach in literature employs macroeconomic data to test the validity of
RET (Barro; 1989; Castro and Fernandez; 2013; Nanshuwan and Omotunde; 2017). Within this strand, it is common to either employ static aggregate consumption as a function of vector of government deficit finance variables like government expenditure, tax revenue, interest rate, deficit finance, among others (Nanshuwan and Omotunde; 2017; Abdulkarim and Saidatulakmal; 2021; Ayunasta et al.; 2020) or employ Euler equations using multivariate regression analysis or VAR models (Barro; 1989; Castro and Fernandez; 2013).

The second strands relies heavily on microeconomics data using laboratories experiment to check the validity of the RET (Adji et al.; 2009). This approach has been fiercely criticized in literature on the ground that it involves hypothetical scenarios and decisions made in a highly artificial environment, thus raising questions about their relevance for daily decision making and casting doubt on their ability to ensure external validity for a representative sample of the population. The third stands employ survey method to check the extent the consumers adjust their consumption relatives to deficit financing (Heinemann and Hennighausen; 2012; Stix; 2013; Parker et al.; 2013; Bernd and Florian; 2017).

Within the studies that employed macroeconomics data, there are varieties in the methodological approach. While some studies like Siddiki (2010), Isiaq and Bolaji (2016) and Frank and Peter (2020) employed government deficit finance variables on private consumption and most found supporting evidence of Keynes that fiscal policy or deficit financing impacts the consumer aggregate spending. Other studies like (Ricciuti; 2003; Normandin; 1999; Amaghionyeodiwe and Akinyemi; 2015) employed government deficit finance variables on current account deficit. While Normandin found supporting evidence for the twin deficit, Ricciuti does not find any existing impact of deficit finance on currency account deficit. The issue with most of these studies is that indirect approach is commonly used to model the relationship which is not sufficient to conclude the existence or not of RET. RET emphasizes situation where tax reduction is accompanied by debt to finance the deficit and argue that individuals do not adjust their consumption upward on the belief that their net wealth has increased. Some of the empirical works within and outside the sore of Nigeria are summarized in Table 1.

Overall, based on the relevant literature reviewed in this paper, there is evidence that RET is valid for so many developed countries. For instance, a strong correlation was found between government debt burdens and net financial assets accumulated in 12 out of the 15 nations when studies were carried out on the effects of the 2008 financial crisis on European Union nations, in such cases, Ricardian equivalence holds up. Also, Countries with high levels of government debt were found to comparatively high levels of household savings (Terazi and Senel; 2011) .

In conclusion, a number of studies of spending patterns in the U.S. have found that private sector savings increase by about 30 cents for every additional \$1 of government borrowing. This suggests that the Ricardian theory is at least partially correct (Belka; 2009).

\section{Research methodology}

\subsection{Data and Sources}

The study sourced all data from the Central Bank of Nigeria (CBN) statistical database. Specifically, quarterly data on Nigeria debt, budget deficit, tax revenue, government expenditure, disposable income, current account deficit, and private con- 
Table 1. Summary of Empirical Literature

\begin{tabular}{|c|c|c|c|}
\hline Author (s) & Methodology & Findings & Issues \\
\hline Hayo \& Neumeier (2016) & $\begin{array}{l}\text { The study employed survey } \\
\text { data using logistic regression to } \\
\text { regress some series on house- } \\
\text { hold consumption choice. }\end{array}$ & $\begin{array}{l}\text { The study found that German } \\
\text { household consumption choices } \\
\text { respond to deficit finance }\end{array}$ & $\begin{array}{l}\text { The study model RET using in- } \\
\text { direct effect and fails to capture } \\
\text { the dynamics effect of RET. }\end{array}$ \\
\hline Artidiatun \& James (2016) & $\begin{array}{l}\text { The study employed ECM and } \\
\text { cointegration to model deficit fi- } \\
\text { nance variables on interest rate, } \\
\text { current account deficit and con- } \\
\text { sumption }\end{array}$ & $\begin{array}{l}\text { The study discovered that fis- } \\
\text { cal policy variables like deficit fi- } \\
\text { nance impact the three indepen- } \\
\text { dent variables and reject the RET } \\
\text { assertion }\end{array}$ & $\begin{array}{l}\text { Like most studies, the study fo- } \\
\text { cused on the indirect effects and } \\
\text { fails to incorporate most of the } \\
\text { assumption of RET in the model }\end{array}$ \\
\hline Teboho and Joel (2017) & $\begin{array}{l}\text { The study employed ARDL tech- } \\
\text { nique where fiscal deficit is mod- } \\
\text { eled against private consump- } \\
\text { tion }\end{array}$ & $\begin{array}{l}\text { It was discovered that deficit fi- } \\
\text { nance particularly government } \\
\text { expenditure has negative rela- } \\
\text { tionship with private consump- } \\
\text { tion }\end{array}$ & $\begin{array}{l}\text { The study like most empirical } \\
\text { RET estimated the indirect re- } \\
\text { lationship and present studies } \\
\text { completely ignore tax }\end{array}$ \\
\hline Saraswati \& Wahyudi (2018) & $\begin{array}{l}\text { The study employed an ARDL ap- } \\
\text { proach where the indirect ap- } \\
\text { proach of modelling private con- } \\
\text { sumption as a function of cur- } \\
\text { rent tax revenue and expendi- } \\
\text { ture }\end{array}$ & $\begin{array}{l}\text { It was discovered that govern- } \\
\text { ment deficit financing variables } \\
\text { had no significant impact on In- } \\
\text { donesian economy which is con- } \\
\text { sistent with RET assumption }\end{array}$ & $\begin{array}{l}\text { Despite validating RET assertion, } \\
\text { the study employed an indirect } \\
\text { approach and ignore tax revenue } \\
\text { ratio to debt }\end{array}$ \\
\hline Marzouk \& Oukhallou (2016) & $\begin{array}{l}\text { It employed OLS to model for- } \\
\text { eign debt as a function of private } \\
\text { consumption }\end{array}$ & $\begin{array}{l}\text { The study validated RET in Mo- } \\
\text { rocco and argue that private con- } \\
\text { sumption is not just influenced } \\
\text { by debt alone }\end{array}$ & $\begin{array}{l}\text { The study application of OLS to } \\
\text { estimate the model produce re- } \\
\text { sult that suffers from endogene- } \\
\text { ity issues }\end{array}$ \\
\hline Amaghionyeodiwe \& Akinyemi (2015) & $\begin{array}{l}\text { The study employed VECM and } \\
\text { granger causality test to deter- } \\
\text { mine the relationship between } \\
\text { budget deficit and current ac- } \\
\text { count deficit }\end{array}$ & $\begin{array}{l}\text { It was discovered that budget } \\
\text { deficit exerts positive influence } \\
\text { on the current account and es- } \\
\text { tablishes a relationship between } \\
\text { both }\end{array}$ & $\begin{array}{l}\text { The model does not incorpo- } \\
\text { rate the assumption of RET and } \\
\text { within the indirect approach, the } \\
\text { model was wrongly specified }\end{array}$ \\
\hline Nanshuwan \& Omotunde (2017) & $\begin{array}{l}\text { The study employed ARDL/bond } \\
\text { to estimate fiscal deficit on sav- } \\
\text { ing }\end{array}$ & $\begin{array}{l}\text { The study found that fiscal } \\
\text { deficit particularly budget deficit } \\
\text { has positive relationship with } \\
\text { savings }\end{array}$ & $\begin{array}{l}\text { The study application of ARDL } \\
\text { was dominated by some estima- } \\
\text { tion or model issues like the } \\
\text { omission of variables and wrong } \\
\text { model }\end{array}$ \\
\hline Isiaq \& Bolaji (2016) & $\begin{array}{l}\text { The study employed, Error Cor- } \\
\text { rection Model and modified OLS } \\
\text { to model fiscal policy on private } \\
\text { consumption }\end{array}$ & $\begin{array}{l}\text { The study found that fiscal } \\
\text { deficit impacts private consump- } \\
\text { tion in Nigeria though the signif- } \\
\text { icance is relatively small }\end{array}$ & $\begin{array}{l}\text { The study has a few issues like } \\
\text { no clear justification for using } \\
\text { ECM and modified OLS }\end{array}$ \\
\hline Ogbuagu \& Omojolaibi (2020) & $\begin{array}{l}\text { The study used Vector Autore- } \\
\text { gression (VAR) technique to es- } \\
\text { timate the response of private } \\
\text { savings and investment to fiscal } \\
\text { deficit }\end{array}$ & $\begin{array}{l}\text { The results reveal that govern- } \\
\text { ment fiscal deficit exerts neg- } \\
\text { ative effects on gross domestic } \\
\text { savings and investment }\end{array}$ & $\begin{array}{l}\text { The endogenization of all the } \\
\text { variables makes it difficult for } \\
\text { one to agree with the researcher } \\
\text { that fiscal deficit impacts sav- } \\
\text { ings and investment, particu- } \\
\text { larly since VAR is not used for } \\
\text { impact analysis }\end{array}$ \\
\hline
\end{tabular}


Table 2. Correlation Matrix table

\begin{tabular}{|l|llllll|}
\hline & Consumption (C) & TAX(T) & GOVT(G) & DEBT (D) & T/D & INF \\
\hline Consumption (C) & 1 & & & & & \\
Tax (T) & 0.04 & 1 & & & & \\
Govt (G) & 0.21 & 0.18 & 1 & & & \\
Debt (D) & 0.08 & -0.06 & 0.38 & 1 & & \\
T/D & 0.01 & 0.03 & 0.04 & 0.01 & 1 & \\
INF & 0.15 & 0.07 & 0.32 & 0.20 & 0.00 & 1 \\
\hline
\end{tabular}

Source: Stata Output

sumption were used between 2001Q1 to 2020Q4. Where a data unit is not available in the quarterly form, the researcher converted the data into quarterly using Stata. All data are logged to ensure consistency in their scale and base.

\subsection{Model Specification}

Following the work of Dalamagas (1992), Sobrino (2013), and Saraswati and Wahyudi (2018), the government sector has a period $t$ flow budget constraint of the form:

$$
\begin{array}{r}
G_{t}=T_{t}+D E F_{t}=T_{t}+D_{t}-D_{t}(i+i)+\Delta H_{t} \\
=T_{t}+\Delta D_{t}+\Delta H_{t} \\
\operatorname{orT}_{t}=G_{t}-\Delta D_{t}-\Delta H_{t}
\end{array}
$$

Where, $T_{t}$ represents tax revenue, $D E F_{t}$ represents budget deficit which is financed by increases in either the monetary base, $\Delta H_{t}$ or the stock of government securities sold to the public, $D_{t}$ represents debt, and $\Delta D_{t}$ represents annual changes in government debt payable to the public With respect to the private sector, the representative agent's period $t$ flow budget constraint (assuming that all capital gains are offset by capital losses in the long run) is given by;

$$
\begin{array}{r}
C_{t}=Y_{t}-T_{t}+A_{t-1}(1+i)-A_{t} \\
T_{t}=Y_{t}-C_{t}-\Delta A_{t}
\end{array}
$$

Where, $C_{t}$ represents private-sector consumption proxied by final consumption expenditure of the household, $Y_{t}-T_{t}$ represents national disposable income, A represents asset Holding household sector. Substituting Equation 1 into Equation 2 gives.

$$
\Delta D_{t}=C_{t}-Y_{t}+G_{t}-\Delta H_{t}-\Delta A_{t}
$$

Rearranging equation (3) by substitution method we can have equation (4) which serves as the key equation for the estimation of consumer response to deficit financing.

$$
\sum_{j=0}^{\infty} \delta^{j} C_{t}=\sum_{j=0}^{\infty} \delta^{j}\left(Y_{t}-\Delta A_{t}-G_{t}+\Delta D_{t}+\Delta H_{t}\right)
$$

The last equation may be viewed as the inter-temporal budget constraint of the private sector which holds under the assumption that this sector fully internalizes the budget constraints of the public sector. Combining the information in Equations ( 3 ) and (4) we can derive the estimated equation for the direct measure of RET.

$\ln C_{t}=\beta_{0}+\beta_{1} \ln D_{t}+\beta_{2} \ln T_{t}+\beta_{3} \ln G_{t}+\beta_{4} \ln T / \Delta D_{t}+\beta_{5} I N F_{t}+\mu_{t}$ (5)
Where INF represents = inflation rate and $\ln T / \Delta D$ represents the ratio of tax revenue to changes in government debt. Most studies erroneously ignore this important variable $(\ln T / \Delta D)$ in RET which assume that as tax revenue decline, debt will be rising to finance the increased expenditure. Apriori, RET states that $\beta_{1}=\beta_{4}=0 ;$ beta $_{2}=0 ;-1 \leq \beta-3 \leq 0 ; \beta_{3}=0$.

\subsection{Estimation Technique}

This study applied dynamic ARDL bounds testing to estimate both the short-run and long-run effects based on its numerous advantages including its ability to mitigate for endogeneity issues, perform better when the series are fractionally integrated, among others (Pesaran et al.; 2001). Equation (5) can be expressed in the ARDL form as given in equation (6):

$$
\begin{array}{r}
\ln C_{t}=\beta_{0}+\sum_{i=1}^{p} \beta_{1} \delta \ln C_{t-i}+\sum_{i=0}^{p} \beta_{2} \Delta \ln D_{t-i^{+}} \\
\sum_{i=0}^{p} \beta_{3} \Delta \ln T_{t-i}+\sum_{i=0}^{p} \beta_{4} \Delta \ln G_{t-i}+\sum_{i=0}^{p} \beta_{5} \Delta T / \Delta \ln D_{t-i^{+}} \\
\sum_{i=0}^{p} \beta_{6} \Delta I N F_{t-i}+\alpha_{1} \ln C_{t-1}+\alpha_{2} \ln D_{t-1}+\alpha_{3} \ln T_{t-1}+ \\
\alpha_{4} \ln G_{t-1}+\alpha_{5} \ln T / \Delta D_{t-1}+\alpha_{6} I N F_{t-1}+\mu_{t}
\end{array}
$$

Where $\ln$ is logarithm function, $\Delta$ is the first difference operator, and $\beta_{0}$ is the drift component. The expression with summation sign $\left(\beta_{1}-\beta_{6}\right)$ represents the short-run dynamics of the model, while the coefficients $\left(\alpha_{1}-\alpha_{6}\right)$ represents the long-run relationship and $\mu_{t}$ is the serially uncorrelated disturbance with zero mean and constant variance. Once it is established that there exists a long-run relationship through the application of bounds cointegration test. The long-run relationship of the ARDL model can be estimated as given in equation (7).

$$
\begin{gathered}
\ln C_{t}=\alpha_{1} \ln C_{t-1}+\alpha_{2} \ln D_{t-1}+\alpha_{3} \ln T_{t-1}+ \\
\alpha_{4} \ln G_{t-1}+\alpha_{5} \ln T / \Delta D_{t-1}+\alpha_{6} I N F_{t-1}+\mu_{t}
\end{gathered}
$$

$$
\begin{array}{r}
\ln C_{t}=\beta_{0}+\sum_{i=1}^{p} \beta_{1} \delta \ln C_{t-i}+\sum_{i=0}^{p} \beta_{2} \Delta \ln D_{t-i^{+}} \\
\sum_{i=0}^{p} \beta_{3} \Delta \ln T_{t-i}+\sum_{i=0}^{p} \beta_{4} \Delta \ln G_{t-i}+\sum_{i=0}^{p} \beta_{5} \Delta T / \Delta \ln D_{t-i^{+}} \\
\sum_{i=0}^{p} \beta_{6} \Delta I N F_{t-i}+\alpha_{1} E C M_{t-i}+\mu_{t}
\end{array}
$$


Table 3. Augmented Dickey-Fuller and Philip Perron Test (trends and intercept)

\begin{tabular}{l|ll|l|ll|l|l}
\hline Variable & ADF Level & 1st Difference. & $\mathrm{I}(\mathrm{d})$ & Philip Perron Level & 1st difference. & $\mathrm{I}(\mathrm{d})$ & Remarks \\
\hline Consumption (C) & -1.7839 & $-7.8837^{* * *}$ & $\mathrm{I}(1)$ & -1.5607 & $-6.3028^{* * *}$ & $\mathrm{I}(1)$ & Stationary \\
Tax (T) & $-2.5638^{*}$ & $-8.9730^{* * *}$ & $\mathrm{I}(1)$ & -1.9773 & $-7.0267^{* * *}$ & $\mathrm{I}(1)$ & Stationary \\
Govt (G) & -1.8042 & $-6.8025 * * *$ & $\mathrm{I}(1)$ & -1.5028 & $-5.6729^{* * *}$ & $\mathrm{I}(1)$ & Stationary \\
T/D & $-6.1869^{* * *}$ & - & $\mathrm{I}(0)$ & $-5.4629 * * *$ & - & $\mathrm{I}(0)$ & Stationary \\
Debt (D) & $-3.1802^{*}$ & $-9.2582^{* * *}$ & $\mathrm{I}(1)$ & $-2.8561^{*}$ & $-7.9203^{* * *}$ & $\mathrm{I}(1)$ & Stationary \\
INF & $-4.2083^{* * *}$ & - & $\mathrm{I}(0)$ & $-3.9304^{* *}$ & - & $\mathrm{I}(0)$ & Stationary \\
\hline
\end{tabular}

Significance is indicated as follows: $* * *, * *$ and $*$ for $1 \%, 5 \%$ and $10 \%$ respectively, all variables are logged except for inflation Source: Authors

Table 4. ARDL Models

\begin{tabular}{|c|c|c|c|}
\hline Variable & Model 1 - Indirect Approach & Model 2 Direct Approach & Model 3 Current a/c plus direct approach \\
\hline Bounds F-Stats & $\begin{array}{l}4.8031^{* * * *} \\
\text { LONG }\end{array}$ & $\begin{array}{l}6.6424 * * * \\
\text { RUN }\end{array}$ & $\begin{array}{l}6.12892^{* * *} \\
\text { MODEL }\end{array}$ \\
\hline Consumption (C) & $0.8124(0.000) * * *$ & $0.831(0.000) * * *$ & $0.897(0.000) * * *$ \\
\hline $\operatorname{Tax}(\mathrm{T})$ & $-0.321(0.034) * *$ & $-0.021(0.057)^{*}$ & $0.048(0.066) *$ \\
\hline Govt (G) & $0.426(0.006) * * *$ & $0.027(0.037)^{* *}$ & $0.053(0.043) *$ \\
\hline Debt (D) & $0.262(0.067)^{*}$ & $0.088(0.112)$ & $-0.135(0.050) * *$ \\
\hline $\mathrm{T} / \mathrm{D}$ & - & $0.013(0.12)$ & $0.008(0.213)$ \\
\hline INF & $0.433(0.042) * *$ & $0.434(0.045) * *$ & $0.311(0.034) * *$ \\
\hline $\mathrm{C}$ & $-4.453(0.000) * * *$ & $5.254(0.0232) * *$ & $4.183(0.033) * * *$ \\
\hline $\mathrm{R} 2$ & 0.8364 & 0.2143 & 0.3255 \\
\hline$F^{*}(p-$ value $)$ & $0.0000 * * *$ & $0.0000 * * *$ & $0.0000 * * *$ \\
\hline \multirow[t]{2}{*}{ Breusch-g } & 0.5638 & 0.4327 & 0.4240 \\
\hline & SHORT & RUN & MODEL \\
\hline Consumption $(\mathrm{C}-1)$ & $0.839(0.000) * * *$ & $0.842(0.000) * * *$ & $0.846(0.000)^{* * *}$ \\
\hline $\operatorname{Tax}(\mathrm{T})$ & $-0.438(0.021) * *$ & $-0.014(0.026) * *$ & $0.024(0.065)^{*}$ \\
\hline Govt (G) & $0.240(0.012)^{* * *}$ & $0.052(0.052)^{* *}$ & $0.021(0.000) * * *$ \\
\hline Debt (D) & $0.424(0.012)^{* * *}$ & $0.032(0.2663)$ & $-0.332(0.090) * *$ \\
\hline $\mathrm{T} / \mathrm{D}$ & - & $0.076(0.167)$ & $0.043(0.340)$ \\
\hline INF & $-0.542(0.04) * *$ & $-0.142(0.031) * *$ & $0.388(0.096) * * *$ \\
\hline $\mathrm{C}$ & $8.083(0.000) * * *$ & $-5.071(0.055)^{*}$ & $7.068(0.000) * * *$ \\
\hline $\operatorname{ECM}(-1)$ & $-0.5423(0.000) * * *$ & $-0.5476(0.000) * * *$ & $-0.4231(0.001) * * *$ \\
\hline $\mathrm{R} 2$ & 0.7683 & 0.2065 & 0.5193 \\
\hline $\mathrm{F}^{*}(\mathrm{p}$-value $)$ & 0.0000 & $0.0000 * * *$ & $0.0003 * * *$ \\
\hline Breusch-g & 0.5367 & 0.2419 & 0.4230 \\
\hline
\end{tabular}

Significance is indicated as follows: $* * *, * *$ and $*$ for $1 \%, 5 \%$ and $10 \%$ respectively, all variables are logged except for inflation Source: Authors

\section{Result and Discussion}

To be sure that there is no incidence of high correlation between government debt and the ratio of tax and change in government debt, the study checks for the possible presence of multicollinearity in the series as presented in Table 2. The data in Table (2) revealed that there is no presence of multicollinearity in the series as the highest correlation is 0.38 . Having established that there is no multicollinearity in the model the study proceeded to check for the presence or absence of stationarity in the series.

Economic models are built on the assumption that series are stationary at level. The stationarity result is presented in Table (3) using both the Augmented Dickey-Fuller (ADF) test and Philip Perron (PP) test.

The result as in Table (3) reveals that all the series are either integrated of order zero, I(0) or integrated of order one, I(1). Since the series have fractionally integrated the choice of ARDL is further justified. The study employed a combination of Akaike Information Criterion (AIC), Schwarz Criterion (SC), and Hannan-Quinn Criterion (HQ) for the appropriate lag selection, and where there is a conflict between the various criteria, AIC overrides others following the example of Tonuchi and Onyebuchi (2019).
To establish the existence of long-run relationship between and among the series, the study followed the suggestion of Joseph et al. (2021) to conduct three basic check tests; the bounds co-integration test to validate the existence of longrun relationship, the Breusch-Godfrey Serial Correlation test, and CUSUM square test to check stability of the model. The result of both the long-run and short-run analyses of the ARDL is presented in Table (4).

The data from Table 4 clearly revealed that there is an existence of long-run relationship judging by the value of the bond estimate value. Specifically, for the three models, there exists long-run relationship between and among the series, and cusum stability test as revealed in the appendix revealed that each of the models is stable and consistent which increases our trust in the series. The data from Table 4 revealed that at the first instance when the series is modeled without including strict RET assumption of a simultaneous increase in debt and tax reduction in the model, most of the series of fiscal policy deficit - debt, tax revenue, and government expenditure were significant in driving consumption at 5 percent level of significance.

For instance, in model 1 when T/D was not included, we see that all the government finance deficit variables (debt, tax 
revenue, and government expenditure) are significant at 5 percent level of significance in the short-run and long-run. This finding is consistent with several previous literature likeRomer and Romer (2010), Favero and Giavazzi (2012) both in US; for Germany: Hayo and Uhl (2014); for the United Kingdom: Cloyne (2013); for Nigeria: Abdulkarim and Saidatulakmal (2021). But as argued earlier, these studies ignored the most important variables in RET. In the second model, the study introduced a direct measure of RET and as expected the introduction of ratio of taxation and changes to government debt validate the Ricardian Equivalence assertion. As seen in Table 4, with the introduction of the key RET variable, most of the series which earlier appears to influence consumption becomes insignificant at 5 percent level of significance, particularly in the long-run. As revealed, deficit financing captured by government total debt and ratio of tax revenue to debt is not significant at 5 percent level of significance which means RET assertion is validated contrary to what is obtainable in literature. However, the present study is consistent with the study of Carlos (2001) and Saraswati and Wahyudi (2018) who found evidence in support of RET assumption.

Banday and Aneja (2017) argued that the stack divergence in the findings supporting Keynes or Ricardian theory in the empirical literature is driven by differences in estimating techniques, differences in modeling approach, lack of adequate understanding of RET assumption which is not captured in the most empirical literature. The result is model three where we regressed government deficit finance variables against trade deficit (current account deficit), it was clear that most of the deficit finance variables still do not have any meaningful impact on the deficit finance which means there was no twin deficit in the case of Nigeria. One possible cause might be because Nigeria's debt is dominated by foreign debt-financed with foreign currency. Another possible explanation is that Nigeria is a mono-product company which means that even if there is an interest rate differential, investors will not be induced by such differential and rather consider other factors in their investment decision making.

As revealed in this paper, only debt has a significant impact on the current account deficit as expected, this means that simultaneous changes in both tax revenue and debt do not impact the current account deficit which is consistent with the RET assumption. Inflation in each of the models has significant impacts on consumption which means that private consumption significantly responds to inflation. This is a possible explanation while the gain made by deficit financing are eroded by stagflation as argued by RET. When there is inflation, a rise in disposable income equivalent to the inflation rate means that the real income remains unchanged which possibly explains why deficit finance does not impact aggregate consumption, especially in the long-run. The ECM coefficient from the three models reveals that each of the models can adjust to short-run disequilibrium in the long-run.

\section{Conclusion and Policy Implication}

The study reveals that fiscal deficit financing variables have no significant impact on Nigeria's aggregate consumption which is consistent with Ricardian postulation. Several conclusions can be drawn from the study. First, the study concludes that fiscal deficit finance impacts on Nigeria's aggregate consumption is little or has no impacts. Secondly, that previous works on the subject that have found overwhelming support for Keynes's postulation and rejected Ricardian postulation follow an indirect approach in measuring the assumption of Ricardian, which makes it difficult to reconcile those studies with the present study. Thirdly, when the present study ignored the major variable in Ricardian assumption, most of the fiscal deficit financing variables are significant at 5 percent (see model 1 result in table 4 ) consistent with previous studies which adopted this approach.

Similarly, the fact that inflation in all the models has a significant impact on consumption reveals that the short-run gains from the fiscal deficit might be eroded away by inflation as money losing its value the increased disposable income or increased net wealth of the consumers are ripped off by the loss in the value of money. The policy implication is that policymakers should be mindful of deficit financing particularly as it impacts the country's inflation rate and exchange rate values which play important roles in attracting the requisite investments needed to grow the economy. Policymakers should be sure of what is important to them when going for deficit financing by looking at the structure of the economy in terms of diversification, institution, and policy framework needed to utilize the benefit from the deficit financing, otherwise, the little benefits from deficit finance might be eroded away by other structural issues that accompany deficit financing like fiscal unsustainability, stagflation, exchange rate crises, among others.

\section{Competing Interests}

Author declare no competing interests.

\section{References}

Abdulkarim, Y. and Saidatulakmal, M. (2021). Asymmetric impact of fiscal policy variables on economic growth in nigeria, Journal of Sustainable Finance and Investment 22(1): 1-8.

Adji, A. and Alm, J. (2016). Testing for ricardian equivalence in indonesia, Journal of Contemporary Economic and Business Issues 3(1): 5-31.

Adji, A., Alm, J. and Ferraro, P. J. (2009). Experimental tests of ricardian equivalence with distortionary versus nondistortionary taxes, Economics Bullion 29: 2556-2572.

Amaghionyeodiwe, L. A. and Akinyemi, M. O. (2015). Twin deficit in nigeria: A re-examination, Journal of Economic and Social Studies 5(2): 149-179.

Ayunasta, P., Setiaji, B. and Hakim, L. (2020). Debt and consumption in indonesia: Ricardian equivalence approach, Issues on Inclusive Growth in Developing Countries 1(1): 49-60.

Banday, U. J. and Aneja, R. (2017). Does fiscal deficit affect current account deficit in india? an econometric analysis. Review of Market Integration 9(3): 155-174.

Barro, R. J. (1974). Are government bonds net wealth?, Journal of Political Economy 82: 1095-1117.

Barro, R. J. (1989). The ricardian approach to budget deficits, Journal of Economic Perspectives 3(2): 37-54.

Belka, M. (2009). The global economic crisis is testing the cohesion of the european union, IMF Publications Finance and Development 2: 1-8.

Bernd, H. and Florian, N. (2017). The (in)validity of the ricardian equivalence theorem-findings from a representative german population survey, Journal of Macroeconomics 51: $162-174$.

Carlos, F. M. (2001). Ricardian equivalence: an empirical application to the portuguese economy, Center for Economic Studies Discussions Paper Series (DPS) 01(12).

Castro, F. and Fernandez, J. L. (2013). Does ricardian equivalence hold? the relationship between public and private 
saving in spain, Journal of Applied Economics 16(2): 251-274.

Cloyne, J. (2013). Discretionary tax changes and the macroeconomy: new narrative evidence from the united kingdom, American Economic Review 103: 1507-1528.

Dalamagas, B. A. (1992). Testing ricardian equivalence: a reconsideration, Applied Economics 24(1): 59-68.

Emana, D. (2021). The relationship between budget deficit and economic growth: Evidence from ethiopia, Applied Journal of Economics, Management and Social Sciences 2(2): 10-15. URL: https://nokspublishing.com/index.php/AJMSS/article/view/12

Ezeabasili, V. N. and Egbunike, P. A. (2014). Fiscal deficit and private consumption: the nigerian experience, Journal of Emerging Issues in Economics, Finance and Banking 3(5): 11971209.

Favero, C. and Giavazzi, F. (2012). Measuring tax multipliers: The narrative method in fiscal vars, American Economic Journal: Economic Policy 4: 69-94.

Frank, O. and Peter, K. (2020). Testing the existence of the ricardian equivalence in ghana in this 21st century, International Journal of Applied Research in Management and Economics 2(2): 16-27.

Hayo, B. and Uhl, M. (2014). Taxation and Consumption: Evidence from a Representative Survey of the German Population, MAGKS Discussion Paper.

Heinemann, F. and Hennighausen, T. (2012). Understanding Public Debt Preferences, FinanzArchiv: Public Finance Analysis 68(4): 406-430

Isiaq, O. O. and Bolaji, A. A. (2016). Fiscal policy and term structure of interest rate in nigeria, Acta Universitatis Danubius. OEconomica 12(2): 70-83.

Joseph, E. T. (2020). How to improve mobile money service usage and adoption by nigerians in the era of covid-19, International Journal of Finance, Insurance and Risk Management 10(3): 31-52.

Joseph, T. E., Nwolisa, C. U., Obikaonu, P. C. and Alase, G. (2021). Monetary policy effectiveness and financial inclusion in nigeria: Fintech, 'the disrupter' or 'enabler', International Journal of Applied Economics, Finance and Accounting 9(1): 19-27.

Modigliani, F. and Ando, A. K. (1957). Tests of the life cycle hypothesis of savings: Comments and suggestions, Bulletin of the Oxford University Institute of Economics and Statistics 19(2): 99-124.

Saraswati, B. D. and Wahyudi, S. T. (2018). The effect of fiscal policy on the indonesian household consumption: the ap-
Nanshuwan, V. D. and Omotunde, O. (2017). An examination of the validity of ricardian equivalence hypothesis in nigeria, Journal of Economics and Sustainable Development 8(5): 117125.

Normandin, M. (1999). Budget deficit persistence and twin deficits hypothesis, Journal of International Economics 49(1): 171-193.

Ogbuagu, M. I. and Omojolaibi, J. A. (2020). Interrelationship between fiscal deficit, aggregate savings and investment: a test of ricardian equivalence hypothesis in nigeria, Tanzanian Economic Review 10(1): 53-70.

Parker, J. A.and Souleles, N. A., Johnson, D. S. and McClelland, R. (2013). Consumer spending and the economic stimulus payments of 2008, American Economic Review 103: 25302553.

Pesaran, H., Shin, Y. and Smith, R. (2001). Bounds testing approaches to the analysis of level relations, Journal of Applied Econometrics 16(1): 289-326.

Ricciuti, R. (2003). Assessing ricardian equivalence, Journal of Economic Surveys 17(1): 55-78.

Romer, C. D. and Romer, D. H. (2010). The macroeconomic effect of tax changes: estimates based on new measures of fiscal shocks, Am. Econ. Review 100(1): 763-801.

plication of the ricardian equivalence hypothesis, Review of Integrative Business and Economics Research 7(4): 90-98.

Siddiki, J. U. (2010). The ricardian equivalence hypothesis: evidence from bangladesh, Applied Economics 42(11): 1419-1435.

Sobrino, C. R. (2013). The twin deficits hypothesis and reverse causality: A short-run analysis of peru, Journal of Economics Finance and Administrative Science 18(34): 9-15.

Stix, H. (2013). Does the broad public want to consolidate public debt? the role of fairness and of policy credibility, Kyklos 66: 102-129.

Terazi, E. and Senel, S. (2011). The effects of the global financial crisis on the central and eastern european union countries, International Journal of Business and Social Science 2(17): 1-8.

Tonuchi, J. and Onyebuchi, N. (2019). Economic diversification in nigeria: The role of agriculture and manufacturing sector, International Journal of Electrical and Computer Engineering 7: $916-926$.

Umer, J. B. and Ranjan, A. (2019). Ricardian equivalence: Empirical evidence from china, Asian Affairs: An American Review 1: $1-18$.

URL: https://doi.org/10.1080/oo927678.2019.1639003 